\begin{tabular}{|l|l|}
\hline & $\begin{array}{l}\text { Jurnal Bimbingan dan Konseling Ar-Rahman } \\
\text { Volume 4, Nomor 1, Tahun } 2018 \\
\text { Tersedia Online: } \text { http://ojs.uniska.ac.id/index.php/BKA } \\
\text { e-ISSN 2477-6300 }\end{array}$ \\
\hline
\end{tabular}

\title{
TEKNIK SOSIOMETRI DALAM ASESMEN PELAYANAN KONSELING PADA KEPALA SEKOLAH DAN GURU SDN KUIN SELATAN 1 BANJARMASIN
}

\author{
Muhammad Yuliansyah, Murdiansyah Herman \\ Program Studi Bimbingan dan Konseling Fakultas Keguruan dan Ilmu Pendidikan Universitas Islam Kalimantan \\ M A B Banjarmasin \\ m.yuliansyahy@yahoo.com
}

\begin{abstract}
ABSTRAK
Guru pembimbing sekolah harus memiliki kompetensi profesionalisme dalam kulaifikasi akademik disertai dengan mempunyai kompetensi konselor agar mampu menghadapi berbagai problem sekolah, sehingga guru pembimbing mampu untuk mempersiapkan diri dalam menghadapi perkembangan dunia pendidikan dengan berbagai macam dampak yang bisa menghabat perkebangan siswa disekolah.guru pembimbing disekolah bukan suatu yang lahir tanpa syarat,artinya seseuatu hadir begitu saja tanpa proses belajar yang panjang. Proses yang akhirnya menjadikan guru pembimbing sebagai agen pemebelajaran yang memiliki posisi strategis untuk melakukan berbagai perubahan, peningkatan dan pengembangan dalam penyelenggaraan pendidikan disekolah yang tentunya proses pendidikan disekolah berkesinangbungan dan meningkatkan pengetahuan.
\end{abstract}

Kata Kunci: Pelayanan Konseling; Kepala Sekolah; Guru Pembimbing

\section{ABSTRACT}

School guidance teachers must have professionalism competence in academic qualifications accompanied by having counselor competencies to be able to deal with various school problems, so that the mentoring teacher is able to prepare themselves in the face of the development of the world of education with various kinds of impacts that can hinder students' development in schools. who was born unconditionally, meaning someone just present without a long learning process. The process that ultimately makes the tutor teacher as a learning agent who has a strategic position to make various changes, enhancements and development in the implementation of school education is certainly the process of education in schools that are connected and increase knowledge.

Keywords: Counseling Services; Headmaster; Guidance Teacher

Dipublikasikan Oleh :

UPT Publikasi dan Pengelolaan Jurnal

Universitas Islam Kalimantan Muhammad Arsyad Al-Banjari Banjarmasin 


\section{PENDAHULUAN}

Asesmen dalam bimbingan dan konseling dapat berupa teknik tes dan non tes. Gantina Komalasari, dkk (2011: 22) menjelaskan,' 'bahwa asesmen teknik nontes paling banyak dilakukan oleh konselor". Prosedur perancangan, pengadministrasian, pengolahan, analisis, dan penafsirannya relatif lebih sederhana sehingga mudah untuk dipelajari dan dipahami. Berbagai bentuk asesmen teknik non tes yang selama ini sering digunakan antara lain pedoman wawancara, observasi, angket, sosiometri, pemeriksaan fisik dan kesehatan, tes hasil belajar, tes hasil psikologis, biografi, studi dokumentar, studi kasus, dll.

Asesmen teknik non tes yang akan menjadi bahan acuan penelitian di sini adalah teknik sosiometri.

Sosiometri disebut pula sebagai metode menemukan dan memanipulasikan konfigurasikonfigurasi (bentuk dan formasi), dengan mengukur daya tarik/daya saling tarik menarik dan daya tolak antara para individu dalam suatu kelompok.

Dewa Ketut Sukardi (2008:190) menjelaskan,"'Sosiometri banyak dipergunakan untuk mengumpulkan data tentang dinamika kelompok".Tes sosiometri menghasilkan data atau informasi mengenai jaringan-jaringan komunikasi dalam kelompok-kelompok tertentu, yang terdiri dari 10-50 orang; satu kelas disekolah dapat merupakan kelompok semacam itu.

Dengan diadakannya kegiatan sosiometri ini, akan membantu mempermudah seorang guru pembimbing (konselor) untuk mengetahui keadaan sosial yang terjadi pada siswa dan masalah -masalah yang ada dalam hubungan sosial siswa, dengan diketahuinya masalah-masalah tersebut maka akan mempermudah seorang guru pembimbing (konselor) dalam proses pemberian layanan bimbingan dan konseling yang tepat kepada siswa yang bersangkutan.

\section{PEMBAHASAN}

Secara etimologis kata filosofis atau filsafat merupakan bahasa Arab yang berasal dari kata Yunani filosofia (Philosophia). Filisofia merupakan kata majemuk yang terdiri dari kata filo (philos) yang artinya cinta dalam arti yang seluas-luasnya, yaitu ingin mengetahui segala sesuatudan sofia (shopos) artinya kebijaksanaan atau hikmah. Dengan demikian, filsafat itu artinya cinta kepada kebijaksanaan atau hikmah; atau ingin mengerti segala sesuatu secara mendalam.

Ahli filsafat lain mengartikan bahwa filsafat tersebut adalah "suatu usaha manusia untuk memperoleh pandangan atau konsepsi tentang segala yang ada, dan apa makna hidup manusia di alam semesta ini." Pribadi Dapat diartikan juga sebagai perenungan atau pemikiran tentang kebenaran, keadilan, kebaikan, keindahan, religi serta sosial budaya.

Landasan filosofis berkenaan dengan pandangan terhadap makna atau hakikat manusia. Hakikat manusia adalah suatu pandangan mengenai bagaimana manusia itu sebenarnya.Pemaknaan terhadap hakikat manusia tersebut biasanya dikembangkan sesuai dengan pendekatan suatu teori dalam bimbingan dan konseling. Di bawah ini terdapat beberapa para ahli /mazab konseling yang memaparkan tentang hakikat manusia, yaitu :

1. Menurut Terapi Psikoanalisa (S. Freud, C.G. Yung dan A. Adler)

Baik buruknya perilaku manusia ditentukan oleh energi biologis-psikis dan pengalaman masa dini. motif-motif dan konflikkonflik tak sadar adalah sentral dalam tingkah laku sekarang. Dorongan-dorongan instink sangatlah kuat, tingkah laku orang didorong oleh kekuatan seksual dan agresif. Perkembangan dini sangat penting karena masalah-maslaah kepribadian berakar pada konflik-konflik masa kanak-kanak yang diresepsi.

2. Menurut Terapi Eksestensial humanistik (May, A. Maslow dan V. Frankl)

Berfokus pada sifat dari kondisi manusia yang mencakup kesanggupannya untuk dapat menyadari diri, bebas memilih untuk menentukan nasib sendiri, kebebasan dan bertanggung jawab, kecemasan sebagai sifat unsur dasar, pencarian makna yang unik di dalam dunia yang tak bermakna, berada sendirian dan berada dalam hubungan dengan orang lain, keterhinggaan dan kematian dan kecenderungan mengaktualisasikan diri.

3. Terapi Client Centred (Carl R. Roger)

Memandang manusia secara posittif, manusia meiliki suatu kecenderungan ke arah berfungsi penuh. Dalam konteks hubungan trapeutik klien mengalami perasaan-perasaan yang sebelumnya diingkari. Klien mengaktualisasikan potensi dan bergerak ke arah meningkatkan kesadaran, spontanitas, kepercayaan kepada diri dan keterarahan secara mendalam.

4. Terapi Gestalt (Fritz Perls)

Klien terdorong ke arah keseluruhan dengan mengintegrasi pikiran dan perasaan beserta tingkah laku. Pandangannya anti deterministik, dalam artian bahwa individu meiliki kesanggupan untuk menyadari bagaimaan pengaruh masa lampau berkaitan dengan amsa sekarang.

5. Terapi Analisis Transaksional (Eric Berne) 
Klien dipandang memiliki kemampuan untuk meilih. Apa yang sebelumnya ditetapkan, bisa ditetapkan ulang. Meskipun klien bisa menjadi korban dari putusan-putusan dini dan skenario kehidupan. Aspek-aspek yang mengalahkan diri bisa diubah dengan kesadaran.

6. Terapi Tingkah Laku (Lazarus, Salter, Wolpe)

Menerapkan prinsif-prinsif belajar dalam menyelesaikan gangguan-gangguan tingkah laku yang spesifik. Hasilnya dijadikan bahan eksperimentasi lebih lanjut. Terapi tingkah laku dilakukan secara berkesinambungan dalam proses penyempurnaan.

7. Tearapi Rasioanl Emotf (Albert Ellis)

Manusia dilahirkan dengan potensi untuk berpikir rasional, tetapi juga dengan kecenderungan bersikap emosional, sehingga cenderung ke arah berfikir yang curang. Mereka cenderung menjadi korban dari keyakinankeyakinan yang irasional, tetapi juga menekankan berpikir, menilai, menganalisis dan memutuskan ulang. Terapi bersifat didaktis, berorientasi kognitif-tindakan serta menekankan pemikiran dan sistem kepercayaan sebagai akibat masalah pribadi.

8. Terapi Realitas (William Glasser)

Orang yang membutuhkan identitas dan bisa mengembangkan identitas keberhasilan serta identitas kegagalan. Terapi dilakukan dengan berlandaskan motivasi pertumbuhan dan anti eterministik. Terapi bersifat jangak pendek, berfokuspada saat sekarang, menekankan kekuatan pribadi, dan pada dasarnya merupakan jalan di mana klien bisa belajar tingkah laku yang lebih realistis sampai bisa mnecapai keberhasilan (Ady, Jarkawi, dan Hamzah, 2012).

Bidang - bidang pelayanan bimbingan dan konseling yaitu:

1. Pengembangan kehidupan pribadi, yaitu bidang pelayanan yang membantu peserta didik dalam memahami, menilai dan mengembangkan potensi dan kecakapan bakat dan minat, serta kondisi sesuai dengan karakteristik kepribadian dan kebutuhan dirinya secara realistik.

2. Pengembangan kehidupan sosial, yaitu bidang pelayanan yang membantu peserta didik dalam memahami dan menilai serta mengembangkan kemampuan hubungan sosial yang sehat dan efektif dengan teman sebaya, anggota keluarga, dan warga lingkungan social yang lebih luas.

3. Pengembangan kemampuan belajar, yaitu bidang pelayanan yang membantu peserta didik mengembangkan kemampuan belajar dalam rangka mengikuti pendidikan sekolah dan belajar secara mandiri.
4. Pengembangan karier, yaitu bidang pelayanan yang membantu peserta didik dalam memahami dan menilai informasi, serta memilih dan mengambil keputusan karier.

\section{Prinsip - Prinsip Bimbingan dan Konseling}

Terdapat beberapa prinsip dasar yang dipandang sebagai pedoman atau landasan bagi pelayanan bimbingan. Prinsip-prinsip ini berasal dari konsep-konsep filosofis tentang kemanusiaan yang menjadi dasar bagi pemberian pelayanan bantuan atau bimbingan. Prinsip-prinsip bimbingan konseling itu adalah:

1. Bimbingan dan konseling diperuntukkan bagi semua siswa. Prinsip ini berarti bahwa bimbingan diberikan kepada semua siswa, baik yang tidak bermasalah maupun yang bermasalah, baik pria maupun wanita. Dalam hal ini pendekatan yang digunakan dalam bimbingan lebih bersifat preventif dan pengembangan dari pada penyembuhan (kuratif) dan lebih diutamakan teknik kelompok dari pada perseorangan (individual).

2. Bimbingan dan konseling sebagai proses individuasi. Setiap siswa bersifat unik (berbeda satu sama lainnya), dan melalui bimbingan siswa dibantu untuk memaksimalkan perkembangan keunikannya tersebut. Prinsip ini juga berarti bahwa yang menjadi fokus sasaran bantuan adalah konseli, meskipun pelayanan bimbingannya menggunakan teknik kelompok.

3. Bimbingan menekankan hal yang positif. Dalam kenyataan masih ada siswa yang memiliki persepsi yang negatif terhadap bimbingan, karena bimbingan dipandang sebagai satu cara yang menekan aspirasi. Sangat berbeda dengan pandangan tersebut, bimbingan sebenarnya merupakan proses bantuan yang menekankan kekuatan dan kesuksesan, karena bimbingan merupakan cara untuk membangun pandangan yang positif terhadap diri sendiri, memberikan dorongan, dan peluang untuk berkembang.

4. Bimbingan dan konseling merupakan usaha bersama. Bimbingan bukan hanya tugas atau tanggung jawab konselor, tetapi juga tugas guruguru dan kepala sekolah sesuai dengan tugas dan peran masing-masing. Mereka bekerja sebagai teamwork.

5. Pengambilan keputusan merupakan hal yang esensial dalam bimbingan dan konseling. Bimbingan diarahkan untuk membantu konseli agar dapat melakukan pilihan dan mengambil keputusan. Bimbingan mempunyai peranan untuk memberikan informasi dan nasihat kepada siswa, dimana itu semua sangat penting baginya dalam mengambil keputusan. Kehidupan siswa 
diarahkan oleh tujuannya, dan bimbingan memfasilitasi siswa untuk mempertimbangkan, menyesuaikan diri, dan menyempurnakan tujuan melalui pengambilan keputusan yang tepat. Kemampuan untuk membuat pilihan secara tepat bukan kemampuan bawaan, tetapi kemampuan yang harus dikembangkan. Tujuan utama bimbingan adalah mengembangkan kemampuan siswa untuk memecahkan masalahnya dan mengambil keputusan.

\section{Pengertian Sosiometri}

Sosiometri merupakan metode pengumpulan data tentang pola dan struktur hubungan antara individu-individu dalam suatu kelompok. dengan cara menelaah relasi sosial dan status sosial. Metode ini dikembangkan oleh Moreno dan Jenning. Metode ini didasarkan pada pemikiran bahwa kelompok struktur yang terdiri dari hubungan-hubungan interpersonal yang kompleks. Posisi setiap individu dan hubunganhubungan yang terjadi dalam struktur kelompoknya dapat diukur secara kualitatif dan kuantitatif (Gantina Komalasari,dkk, 2011:95).

Sosiometri adalah alat untuk meneliti struktur sosial dari suatu kelompok individu dengan dasar penelaahan terhadap relasi sosial dan status sosial dari masing-masing anggota kelompok yang bersangkutan.

Sosiometri adalah alat untuk dapat melihat bagaimana hubungan sosial atau hubungan berteman seseorang. Sosiometri merupakan suatu metode untuk memperoleh data tentang hubungan sosial dalam suatu kelompok, yang berukuran kecil sampai sedang (10 50 orang), berdasarkan preferensi pribadi antara anggota-anggota kelompok. Sosiometri adalah suatu alat yang dipergunakan mengukur hubungan sosial siswa dalam kelompok.

Dari beberapa pengertian di atas dapat disimpulkan pengertian sosiometri adalah suatu teknik untuk mengumpulkan data tentang hubungan sosial seorang individu dengan individu lain, struktur hubungan individu dan arah hubungan sosialnya dalam suatu kelompok.

Dengan demikian sosiometri dapat mengugkap dinamika sosial, popularitas individu dalam kelompok, serta untuk mengenali kesulitan hubungan sosial individu dalam kelompok.Situasi sosial kelompok dapat berupa kelompok belajar, bermain, pertemanan, kerja kelompok dll.

\section{Bentuk Hubungan dalam Penggunaan Sosiometri}

Berdasarkan data hasil penggunaan sosiometri digambarkan dalam sosiogram dapat diperoleh beberapa bentuk hubungan, yaitu:
1. Hubungan sosial segitiga menggambarkan intensitas hubungan tiga orang individu yang cukup kuat dan intim.

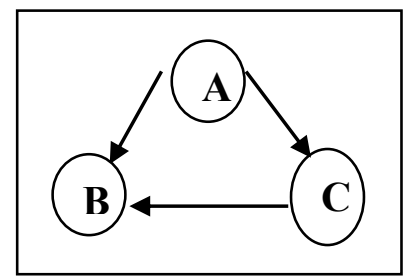

Gambar 1. Sosiogram Bentuk Segitiga

2. Hubungan sosial terpusat, menggambarkan tingkat popularitas seorang individu dalam kelompoknya.

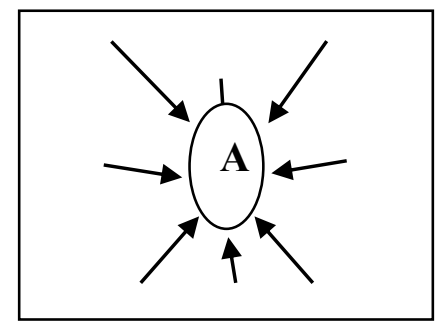

Diagram 2. Sosiogram Terpusat

3. Hubungan sosial intim, menggambarkan hubungan beberapa orang yang saling memilih satu dengan yang lain dengan intensitas hubungan yang kuat.

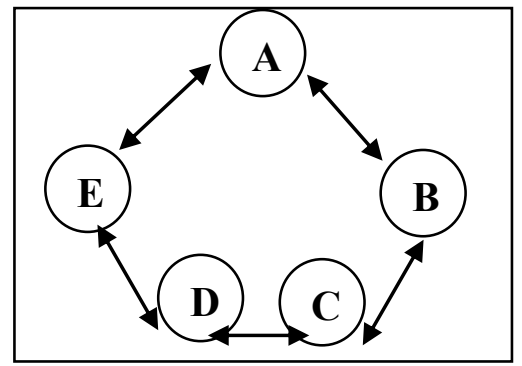

Gambar 3. Hubungan Sosial Intim

4. Hubungan sosial berbentuk jala, menggambarkan pola relasi yang bersifat menyeluruh di mana setiap anggota saling berelasi. Bentuk hubungan ini memiliki intensitas sangat kuat, seluruh kelompok sebagai satu kesatuan yang sukar untuk dipisahkan dan ketidakhadiran seseorang dalam kelompok tidak akan menyebabkan perpecahan atau kerapuhan suatu kelompok. 
Muhammad Yuliansyah dan Murdiansyah Herman Jurnal Bimbingan dan Konseling Ar-Rahman Volume 4, Nomor 1, Tahun 2018 e-ISSN 2477-6300

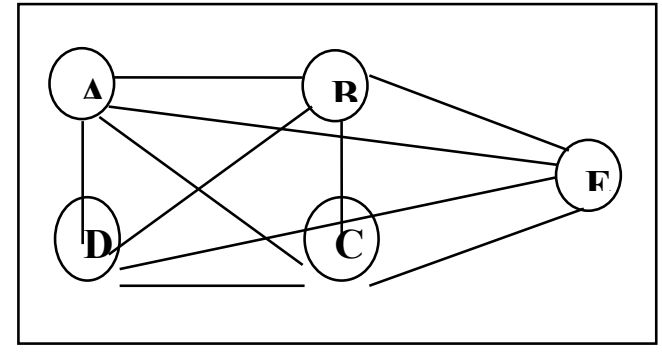

Diagram 4. Bentuk Jala

5. Hubungan berbentuk rantai. Menggambarkan pola hubungan searah atau sepihak dan tidak menyeluruh. Intensitas hubungannya rendah, sehingga relasi kelompok mudah rapuh.

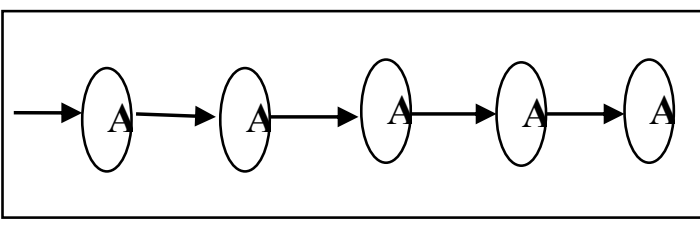

Diagram 5. Sosiogram Bentuk Rantai

\section{PENUTUP}

Penggunaan Sosiometri dalam Asesmen Layanan Konseling Pada Guru SDN Kuin Selatan 1 Banjarmasin sudah berjalan dan dilakukan dengan mulai memahami arti pemahaman dari sosiometri, sesuai yang diharapkan oleh peneliti bahwa di sekolah tersebut yaitu kepala sekolah dan guru mampu menguasai peran dan fungsinya dalam proses penggunaan asesmen lapangan dengan teknik non tes khususnya sosiometri dan dapat dimanfaatkan dan dikembangkan kepada guru dan pemahaman khususnya pada peserta didik agar berjalan sebagaimana mestinya.

Pada penggunaan sosiometri yang diberikan, ada upaya yang dilakukan agar sesuai dengan kebutuhan atau masalah guru seperti penggunaan sosiometri akan disempurnakan dan disesuai dengan situasi sekolah, agar diberikan tidak hanya pada studi kasus saja tetapi pada saat pembagian kelompok belajar atau pembagian guru kelas, adanya satuan layanan asesmen dilakukan oleh peneliti dan hasil penggunaannya tersebut dijadikan sebagai dasar dalam perancangan program Bimbingan dan Konseling atau layanan yang diberikan benar-benar sesuai dengan kebutuhan guru.

\section{REFERENSI}

Ady, N., Jarkawi, dan Hamzah. (2012). Keterampilan Bimbingan dan Konseling/Psikoterapi melalui HABLUM dalam Praktik Pendidikan. Banjarmasin: CV. Hasan Utama.

Dipublikasikan Oleh :

UPT Publikasi dan Pengelolaan Jurnal

Universitas Islam Kalimantan Muhammad Arsyad Al-Banjari Banjarmasin
Hasan, M. (2000). Metode Penelitian Kualitatif. Jakarta: PT. Kirana Cakra Banua.

Komalasari, G., Wahyuni, E dan Karsih. (2011). Asesmen Teknik Nontes dalam Perspektif BK Komprehensif. Jakarta: PT. Indeks.

Kunandar. (2012). Penelitian Tindakan Kelas. Jakarta: Rajawali Press.

Sugiyono. (2013). Metode Penelitian Pendidikan Pendekatan Kuantitatif, Kualitatif, dan R\&D. Bandung: Alfabeta.

Sukardi, D.K., dan Kusmawati, N. (2008). Proses Bimbingan dan Konseling di Sekolah. Jakarta: Rineka Cipta.

Sukardi, D.K. (2008). Pengantar Pelaksanaan Program Bimbingan dan Konseling di Sekolah. Jakarta: Rineka Cipta.

Suleman, F. (2012). http//www.Teknik Angket Sebagai Prosedur Asesmen Dalam Mengidentifikasikan Kecerdasan Sosial Siswa di Sekolah.com.

Suprapto. (2013). Metodologi Penelitian Ilmu Pendidikan dan Ilmu-ilmu pengetahuan Sosial. Yogyakarta: CAPS. 